\title{
Entrepreneurial cognition or judgment: Management and economics approaches to the entrepreneur's choices
}

\section{Marta Gancarczyk ${ }^{1}$ (D), Anna Ujwary-GiP}

\begin{abstract}
Purpose: The explanation of entrepreneurial choices is relevant for efficient resource allocation and wealth of individuals and societies. The economics and management studies in entrepreneurship present both complementary and alternative views on the antecedents of entrepreneurial decisions and actions. This paper aims to synthesize this discussion, propose the processual and configurational approach that bridges the extant views, as well as to present the contribution of the papers in this issue to exploring the link between entrepreneurial cognition and choices. Methodology: Based on the narrative literature review, we present the major constructs describing how entrepreneurs make judgments under uncertainty and select particular decisions and actions. Then, we suggest how these differing assumptions can be adopted within processual view, as well as based on the configurational approach to judgments and actions of entrepreneurs. Findings: The research included in this issue treats the concepts of entrepreneurial discovery and creation as complementary rather than alternative. Moreover, the referred studies acknowledge the role of capabilities, personal traits and entrepreneurial cognition in enterprise performance and intentions to run a business. Additional value of this issue is a broad picture of the context and related contingencies, such as geographical location, industrial and firm idiosyncrasies, as well as economic development and social awareness levels in particular locations. Implications for theory and practice: This paper synthesizes the extant discussion on the antecedents of entrepreneurial choices, and proposes processual and configurational approaches to bridge theoretical perspectives in this research field. Originality and value: We contribute to the literature on entrepreneurial choices by proposing the conceptual links between judgments and
\end{abstract}

\footnotetext{
1 Marta Gancarczyk, Ph.D., Hab., Associate Professor, Department of Finance and International Economics, Institute of Economics, Finance and Management, Faculty of Management and Social Communication, Jagiellonian University, Prof. Stanislaw Lojasiewicz 4, 30-415 Krakow, Poland, e-mail: marta.gancarczyk@uj.edu.pl (ORCID: https://orcid.org/0000-0003-2078-9320).

2 Anna Ujwary-Gil, Ph.D., Hab., Professor of Institute of Economics, Polish Academy of Sciences, Laboratory of Process and Network Analysis, Nowy Swiat 72, 30-330 Warsaw, Poland, e-mail: ujwary@inepan.waw.pl (ORCID: https://orcid.org/0000-0002-5114-7366).
} 
behaviors in economics and management studies, and by highlighting how the research in this thematic issue explains the referred links.

Keywords: uncertainty, opportunity, entrepreneurial cognition, entrepreneurial judgment, the theory of the firm

\section{INTRODUCTION}

Productive entrepreneurship contributes to the well-being of individuals and societies through efficient allocation of resources (Baumol, 1996; Dominiak, Wasilczuk, \& Starnawska, 2016; Gancarczyk, 2019; UjwaryGil, 2019). Therefore, disentangling how entrepreneurs make choices is a fundamental issue both at the micro- and macro-analytical level. The dynamic and idiosyncratic nature of entrepreneurship stems largely from unique entrepreneurial perceptions and judgments (Barney \& Felin, 2013; Foss \& Klein, 2012, 2015; Gaglio \& Katz, 2001; Kirzner, 1997) as well as from environmental contingencies (Welter, 2011; Zahra \& Wright, 2011; Dvouletý $\&$ Orel, 2020). Therefore, explaining entrepreneurial decisions and actions requires both in-depth understanding of cognitions, judgments, personal traits, and contextual conditions for owner-managers, such as currently owned assets and external phenomena and trends (Chen, Mitchell, Brigham \& Howell, 2018; Davidsson, Delmar \& Wiklund, 2006; Dobbs \& Hamilton, 2007; Foss \& Klein, 2015; Packard, 2017; Selden \& Fletcher, 2015). With reference to the antecedents of entrepreneurial choices, the economics and management studies present both complementary and alternative views. These revolve around the major constructs, such as entrepreneurial opportunities, cognition versus judgments, as well as creation or realist, or middle-ground assumptions about the ontological status of opportunity (Kirzner, 1997; Knight, 1921; Foss \& Klein, 2012; Alvarez \& Barney, 2007; Sarason, Dean, \& Dillard, 2006; Ramoglou \& Tsang, 2016).

This paper aims to synthesize the discussion of the antecedents of entrepreneurial choices, propose the processual and configurational approach that bridges the extant views, and present the contribution of the papers in this volume to exploring the link between entrepreneurial cognition and choices. We use narrative literature review to present the major constructs and assumptions regarding how entrepreneurs make judgments in the conditions of uncertainty and select particular decisions and actions. The contribution of this paper rests on proposing the conceptual links between entrepreneurial judgment and choices in economics and management perspectives, and by highlighting how the research in the current thematic issue explains the referred link. 
In the next section, literature review is performed. We structure the discussion on individual-opportunity relationship in different conceptual approaches adjacent to management or economics fields. A processual view is proposed as a conceptual platform to accommodate the views on entrepreneurs' judgments and choices. The following paragraphs refer to the theory of the firm as the theory of entrepreneurship. Transaction cost economics and the resource-based view (RBV) were recommended as theoretical groundings, representing the major perspectives on the nature of the firm rooted in economics and management. By confronting and integrating their assumptions, we propose configurational explanation of owner-managers' judgments, decisions, and actions. Following these conceptual foundations, the paper explains how the studies in this thematic issue contribute to the understanding of the links among entrepreneurial judgments and choices. The section on the implications for future research specifies new promising areas of study, stemming from the presented papers. The conclusion follows.

\section{LITERATURE REVIEW}

\section{Perspectives on individual-opportunity nexus and the processual approach}

Entrepreneurship as nexus of individual and opportunity has long tradition and intuitive relevance for the vast community of scholars and entrepreneurs themselves (Shane, 2012). However, the point of argument in this regard stems from the understanding of the nature of opportunity, which ultimately led to the questioning of usefulness and validity of this construct (Foss \& Klein, 2017; Ramoglou \& Tsang, 2016, 2017; Alvarez, Barney, McBride, \& Wuebker, 2017). Economists laid conceptual foundations of the entrepreneurial activity and its economic importance, with the emphasis on economic rationales of wealth creation through innovation (Schumpeter, 1934). The economics studies acknowledge the importance of individual choices under uncertainty that target opportunity recognition or discovery. The underlying assumption is that opportunities represent objectively existing possibilities. The possibilities are framed by enabling and constraining factors that are exogenous to an individual, such as market trends and needs or external shocks (Marona \& Tomal, 2020). Opportunity is then a construct or metaphor representing the possibilities that are discovered and exploited by alert individuals (Kirzner, 1973; Foss \& Kline, 2015). Entrepreneurs are capable of recognizing possibilities (or market propensities) and actualizing them into wealth through 
commercialized products and services (Ramoglou \& Tsang, 2016, 2017; ). This activity is not merely a discovery, but it consists in the creation of ideas and inventions or in the process of creative destruction (Schumpeter, 1934). Nevertheless, creativity and subjectivity concern how entrepreneurs address external opportunities with products and services rather than opportunity itself. In economics studies, the individual-opportunity nexus is also described as the process of matching the entrepreneur's and firm's capabilities with environmental opportunities, i.e. identifying the fit between internal potential and external conditions (Penrose, 1959).

Kirznerian ideas of alertness and opportunity discovery were further developed into the entrepreneurial discovery stream in management literature, and subsumed as critical realist perspective on entrepreneurial activity (Shane \& Venkataraman, 2000, Shane, 2012). Recently, this approach has also been supported by Ramoglou and Tsang $(2016,2017)$, who capture opportunities under the notion of extant market propensities that are actualized through entrepreneurial cognition, decisions, and actions. In entrepreneurship and technology management studies, the idea of external enablers supports the idea of independent, external conditions that inspire and stimulate entrepreneurial creative action (Briel, Davidsson, \& Recker, 2018;). The concept of external enablers (Briel et al., 2018) emphasizes these determinants of entrepreneurial activity that are external and independent of entrepreneurial judgments and the firm's resources (Götz, 2020a, 2020b; Onwe, Ogbo, \& Ameh, 2020; Marona \& Tomal, 2020).

Nevertheless, other researchers focused on uncertainty, which makes it impossible to infer or identify objective opportunities at the start of creative activity (ex ante). It is only possible to recognize opportunities as embedded in products, markets, and profits (ex post) (Alvarez \& Barney, 2007, Alvarez et al., 2017). Moreover, idiosyncrasies and equfinality in business success or failure within the same external environments point to the importance of internal potential of individuals and firms (Wijaya \& Suasih, 2020). These observations supported subjectivity of the creation process rather than discovering objectively existing opportunities. In the structuration view, the entrepreneur's cognition and action belong to socially-created reality and the individual cognition represents the source of opportunities, as well as explorative rather than exploitative actions to actualize them (Sarason et al., 2006). In this vein, the entrepreneurial cognition and actions are the source of opportunities and the means of actualizing them (Alvarez \& Barney, 2007). The concept of creation entrepreneurs explains entrepreneurial decisions and actions through cognitive processes, nevertheless, it also acknowledges external impacts that stem from other than socially-crated reality, such as objective principles of gravity (Alvarez \& Barney, 2007). In this 
view, opportunities are cognitive processes rather than objective external conditions (Packard, 2017). The studies of entrepreneurial context reflect the blurring limits between external and internal conditions, researching both internal capabilities and external environmental conditions (Welter, 2011).

Recently, the alternative approaches of entrepreneurial discovery vs creation entrepreneurs met some middle-ground perspectives on entrepreneurial choices (Foss \& Klein, 2017). These are concepts of effectuation vs. causation (Sarasvathy, 2001, 2009), bricolage (Baker \& Nelson, 2005), entrepreneurial judgment (Foss \& Klein, 2012) and enabling constraints (Selden \& Fletcher, 2015, among others. Regarding the effectuation logic (Sarasvathy, 2001, 2009), it regards entrepreneurship as emergent process, where decisions and actions are experimental and iterative, arising from the co-evolution of cognitions, the context, and earlier events. The bricolage logic (Baker \& Nelson, 2005), emphasizes the deployment of resources at hand that are reconfigured and used in a novel way. The concept of enabling constraints focuses on the run of events and proposes micro-causalities between entrepreneurial perceptions, behaviors, and artifacts that are at least partially generated by earlier events (such as institutions, extant technologies or business plans) (Selden \& Fletcher, 2015). The entrepreneurial judgment perspective questions opportunities as a relevant construct. Instead, it proposes entrepreneurs' interpretations and evaluations of the context, which is at least partially objective, framing the choices (Foss \& Klein, 2012, 2015). This perspective regards the entrepreneur as exercising judgment about future market conditions, combining and deploying heterogeneous assets and performing ownership of these assets. The judgments (interpretations and evaluations) focus on investment in products and services (asset ownership), and they represent the emergent choices, 'in between' the purely rational and random ones (Foss \& Klein, 2017). The middle-ground perspectives depart from a purely adaptive approach and a determinism of contextual influences, as well as from purely subjective and creative role of entrepeneurs vis a vis opportunities.

The concept of creation entrepreneurship and structuration view (Alvarez \& Barney, 2007; Alvarez et al., 2017; Sarason et al., 2006) focuses on entrepreneurial cognition and perceptions of reality as sources of actions. This approach highlights capabilities, motivations of entrepreneurs, which is relevant for education, training, and assessment of entrepreneurial inclinations. It is also relevant for the explanation of motivations other than purely economic and profit-oriented, such as lifestyle or social rationales in running a business (Gancarczyk, 2006). The understanding of entrepreneurial cognitive and epistemological aspects is especially useful for the policy supporting entrepreneurial attitudes and would-be entrepreneurs. It also 
represents a primary arena for basic research in entrepreneurship, with a view on further application for educational and training purposes. Overall, the primary focus on cognitive processes of owner-managers can be recognized as positive approach that explains how business owners exercise decisions and actions under uncertainty. Nevertheless, the focus and outcomes of this stream are less relevant for incumbent entrepreneurs, who seek practiceoriented, effective choices in business (Ramoglou \& Tsang, 2017). Their pragmatic focus is on market, product, and innovation processes to explore new prospective domains and exploit them for the sake of survival and growth. In this vein, the perspective of entrepreneurial discovery gives insights that are more practice-oriented and normative (Ramoglou \& Tsang, 2017). It helps to screen environmental conditions and be alert to external enablers in uncertain conditions (Briel et al., 2018; Gancarczyk \& Gancarczyk, 2013). Nevertheless, this approach underscores the importance of more nuanced approach to rules of cognition and action.

The middle-ground perspective seeks to address the shortcomings of the above extreme perspectives, applying "in between" approach. The judgment view refers to how entrepreneurs think and make choices, however, the construct of judgment differentiates from cognition. Namely, cognition has a broad scope of perceptions of reality under uncertainty, and is inherently a positive (descriptive) category (Mitchell, Mitchell, \& Randolp-Seng, 2014; Sarason et al., 2006). Judgment refers to interpretations, evaluations, that directly precede decisions and actions. Consequently, it is a normative and action-oriented notion (Kirzner, 1996; Foss \& Klein, 2017). Nevertheless, to build a novel and more useful grounding for research and practice, the middle-ground views need to acknowledge entrepreneurial dynamics ( $\mathrm{Li}$, Murad, Ashraf, Syed, \& Riaz, 2020). This can be accomplished by framing it within entrepreneurial process perspectives.

Entrepreneurial process perspectives regard the flow of events as the primary unit of analysis (Gaweł, 2013; McMullen \& Dimov, 2013; Steyaert, 2007; Venkataraman et al., 2012). Entrepreneurial event, in turn, is a conjunction of decisions and actions (D\&As) (Selden \& Fletcher 2015). The process approach enables to bridge the views, which defined the core of entrepreneurship choices either as cognitive structuration (Packard, 2017; Sarason et al., 2006) or as framed by external enablers and constrainers (Chen et al., 2018; Pryor, Webb, \& Ireland, 2016). We can assume that the start of the process needs exploration of cognitive aspects (idealist perspective). In further steps, when assets are being gathered and deployed, the explanation of the entrepreneurial process needs to draw from realist perspective that acknowledges extant context and non-random choices. Ultimately, within the entrepreneurial process perspective, the extreme views on entrepreneurial 
choices should be complemented by middle-ground concepts that highlight the interactions between the entrepreneurial judgment, action, and the environment (Welter, 2011; Zahra \& Wright, 2011). The process perspective enhances a rich and comprehensive agenda for entrepreneurship research and is valuable for practice. It acts as a platform to accommodate seemingly conflicting views, and to see them as continuum or at least as complementary.

\section{Theory of the firm as the entrepreneurship theory}

The judgment view was largely motivated to restore the economics input to entrepreneurship studies. Holding that the theory of entrepreneurship and the theory of the firm are two sides of the same coin, Foss and Klein (2015) emphasized the entrepreneur as combining, deploying, and owning assets (the firm). By drawing upon and expanding the earlier classical writings of Knight (1921), Kirzner (1997), and Baumol (1996), among others, the judgment view has potential to renew the links between entrepreneurship research and economic targets of entrepreneurs. This conceptual direction enabled refreshing transaction cost economics (TCE) as one of the leading perspectives on the nature of the firm (Williamson, 1985, 1989, 1991; Gorynia, 1999; Borkowska, Klimczak \& Klimczak, 2019). From the viewpoint of entrepreneurial and innovative activity, the understanding of sources and consequences of uncertainty need to be reconsidered in TCE (Hallberg, 2015). Moreover, TCE is often criticized for being static. However, when integrated with the assumptions of the resource-based view of the firm (RBV), it can also capture dynamics and heterogeneity of capabilities (Penrose, 1959; Barney, 1991; Teece, 2007; Ujwary-Gil, 2017; Ujwary-Gil \& Potoczek, 2020; Reissova, Šimsova, Sonntag \& Kučerova, 2020). TCE and RBV propose alternative assumptions as to motives of economic agents, rationales for the existence of firms, as well as modes and mechanisms of governance (Gancarczyk, 2017). Moreover, they have been considerably supported by the empirical evidence, which justifies their integrated adoption when explaining entrepreneurial choices (Argyres \& Zenger, 2012; Chandler, McKelvie \& Davidsson, 2009; Foss, 1993). The alternative lenses of RBV and TCE might be helpful to increase possible interpretations, and thus to better reflect the heterogeneity of entrepreneurship through configurational approach (Gibbert \& Ruigrok, 2010).

In this vein, the heterogeneous entrepreneurial processes can be based on the exploitation and exploration of opportunities through superior capabilities, as proposed by the RBV (Penrose, 1959). On the other hand, in less favorable contexts of capabilities and contractual arrangements, this process might weigh towards transaction cost rationales. The two perspectives 
combined or reconfigured may provide benchmark decisional rules for the entrepreneurs in differing contexts of firm resources and contract conditions.

\section{THE CONTRIBUTIONS}

The papers in this volume explore the links between entrepreneurial capabilities, cognition, and behaviors, adopting a wide range of theoretical and methodological approaches. Mensah, Asamoah, and Saghedi perform extensive literature review regarding how cognitive skills and personal traits complement each other in affecting the entrepreneur's decisions to discover or create opportunities in an uncertain environment. They contribute with an integrated approach to entrepreneurial choices, considering both cognitive and personal characteristics, as well as creation and discovery of opportunities. This conceptual basis for a comprehensive conditions in entrepreneurs choices has been specified in the form of propositions for future research.

Flechas, Kozesinski, and Camargo focus on capability perspective in entrepreneurial choices, in particular, on the role of absorptive capacity (AC) in new ventures. Using a systematic literature review, they identify links between $A C$ and knowledge, innovation, and performance dimensions. The study proposes theoretical input to the knowledge on the role of absorptive capacity in the context of newly created companies, and thus it broadens the entrepreneurship and innovation research. It is also informative for the practice of innovation processes in new firm, identifying potential firm strategies in this area.

The paper by Kovanen explores collaborative approach in social entrepreneurship. A systematic literature review enabled knowledge accumulation and structuring the major theoretical approaches in the field. The author finds ambiguity in the construct of collaboration in social enterprise, and difficulties to measure this phenomenon. Besides the synthesis of the field, the study contributes with critical review of conceptual grounds of collaboration in social entrepreneurship.

Nuryakin broadens extant confirmatory studies on the relationship between entrepreneurial orientation (EO) and the performance of small and medium-sized enterprises (SMEs). It supports significance and positive relationships between the referred constructs in the context of furniture SMEs in central Java. Structural equation modeling enabled additional identification of the mediating effect from relational capabilities on the core relationship studied. Nuryakin expands the extant evidence on the strategic role of entrepreneurial orientation in business performance and strengthens theoretical generalization in this regard. 
Doanh studies the entrepreneurial motivations and cognitions of Vietnamese students. The author investigates interrelations between selfefficacy, attitude towards entrepreneurship, subjective norms, perceived behavioral control, and intention to run a business. Unlike the majority of extant research, this study finds entrepreneurial intention (EI) affected by subjective norms both directly and indirectly. Self-efficacy proved insignificant as moderator between subjective norms and perceived behavioral control. However, it performed this role between attitude towards entrepreneurship and El. This study supports the theory of planned behavior by conforming and nuancing it in the context of Vietnamese would-be entrepreneurs.

Following the focus on entrepreneurial intention, Liu and Liang offer indepth and qualitative investigation of El's antecedents with a focus on social entrepreneurial intention (SEI). Unlike the earlier referred studies, which adopted either literature reviews or quantitative approaches, this research uses the case study method. Based on a comprehensive theoretical framework of $\mathrm{El}$, entrepreneurial event theory and theory of planned behavior, the authors describe, illustrate and explain antecedents of SEI. The paper contributes with an analytical generalization and corroboration of the theoretical framework of SEI with two additional drivers of knowledge capital and work experience, as well as with related conceptual and practical implications.

Another qualitative and in-depth investigation of entrepreneurial motivations and attitudes is focused on specialty coffee businesses in Bangkok, Thailand, and Penang, Malaysia. Azavedo and Gogatz use explorative interviews and they report findings that challenge classical economics assumptions on income and profit maximization. Instead, they find lifestyle and professional passion as dominant motivations. The study supports the view on non-monetary motivations of entrepreneurs and offers theoretical redefinition of entrepreneurial passion as professional excellence or craft passion. Moreover, it is informative for policy-makers and educators.

This thematic issue also hosts two articles published based on the general call for papers. Although not directly linked with the major topics of the current volume, they are valuable for the understanding of entrepreneurship context. Rodríguez-Castro and Aparicio undertake the issue of measuring performance of higher education institutions. They adopt extensive literature review to identify the production models in higher education vis a vis related policy objectives. Moreover, the authors identify types of performance measures, however, they find the means of accomplishing objectives by universities largely underexplored. The paper contributes with the conceptual framework of evaluation functions and capabilities that might be relevant for educational policy and institutions of higher education. Pilelienè and Tamulienè investigate consumer choices, in particular the attitudes and behaviors towards organic 
products, as well as their determinants, in the context of the Lithuanian market. The research broadens the knowledge of consumer choices towards organic goods in the specific national context, and it shows discrepancy between the environmental awareness, the knowledge of qualities of organic products, and purchasing decisions. The results are informative both for business and consumer agents, as well as for policy-makers.

\section{FUTURE RESEARCH}

The papers in this issue offer implications for further theoretical studies and empirical investigations. Regarding theory, Mensah, Asamoah, and Saghedi recommend a combined framework of personality traits and cognitive abilities to study entrepreneurial decisions under uncertainty. They also pave the way to empirical tests by eight propositions that can further be specified to testable hypotheses and operationalized. Other potential research directions are context-specific studies and complexity theory adoption in framing individual-opportunity nexus.

The outlook for future studies in start-up companies' innovation process is offered by Flechas, Kozesinski, and Camargo. They identify interrelated avenues for future studies, such as investigations of individual and cognitive aspects of AC, strategies that new ventures may adopt for knowledge acquisition, as well as fruitful areas for further bibliometric analyses and review efforts.

Kovanen opens an agenda for three areas of future research focused on collaboration in social entrepreneurship. Namely, community and public sector to generate new services, collaboration for resources and employment with a background in power relations among organizations, and collaboration at the network- and micro-levels with a focus on governance issues.

The research by Nuryakin strengthened and nuanced the evidence of the entrepreneurial orientation-performance dependence, by identifying a significant mediator of this relationship. Further studies performed in new contexts might explore this line of deepening the role of EO by testing other mediators that are relevant in these contexts.

The study by Doanh formulates a number of implication that are both substantial and methodological. Resonating with the study by Mensah et al., they recommend the expansion of conceptual framework with personal factors as mediators and moderators of $\mathrm{El}$, as well as with variables reflecting social capital and regulatory framework, among others.

The expansion of entrepreneurial orientation antecedents in future research was proposed by Liu and Liang in the context of a social enterprise. 
Moreover, they recommend their analytical generalization to be further verified in the multi-case and quantitative methodologies that would measure the role of the constructs studied in their investigations.

Based on their findings about motivations of specialty coffee business owners in Bangkok and Penang, Azavedo and Gogatz recommend that future research is more alert to business passion as craft passion rather than profitincome passion. Moreover, further policy studies might explore these types of motivations and related needs of entrepreneurs in the area of advisory and financial measures.

This issue is also enriched by the future research implications from two papers published based on the general call of our journal. In their study on performance drivers and measures, Rodríguez-Castro and Aparicio recommend more research on the ways of accomplishing the university objectives through particular functions and capabilities. The authors propose a functional framework that might be applied in goal-oriented efforts. They also suggest the application of their framework to study the dynamics and transformations in higher education by corroborating and extending the current set of components and variables.

After recognizing the discrepancies between consumer environmental awareness and knowledge and behaviors towards green products, Pileliené and Tamuliene propose the extension of their findings and generalizations to accommodate market contingencies and dynamics. It can also be useful to conduct the studies oriented to designing particular green product marketing strategies.

\section{CONCLUSION}

This paper has synthesized the extant discussion on the antecedents of entrepreneurial choices, and proposed processual and configurational approaches to bridge the extant conceptual approaches. Moreover, we have highlighted the contribution of the studies in this volume to exploring the link between entrepreneurial cognition and choices.

Considering the range of topics, constructs, and approaches, the research presented in this volume treats the concepts of entrepreneurial discovery and creation as complementary rather than alternative. Moreover, the referred studies acknowledge the role of capabilities, personal traits and entrepreneurial cognition in enterprise performance and intentions to run a business. Additional value of this volume is a broad picture of the context and related contingencies, such as geographical location, industrial and firm idiosyncrasies, as well as economic development and social 
awareness levels in particular locations. The richness of findings, conclusions and recommendations in the presented research was also due to a wide range of methodologies, ranging from literature reviews, to quantitative, to qualitative studies, allowing for both statistical and analytical generalizations. We believe that this thematic issue brings new insights and broadens our understanding of the links between entrepreneurial cognition, capabilities, and behaviors. Besides expanding knowledge in the research field, it can also benefit practitioners and policy-makers.

\section{References}

Alvarez, S. A., Barney, J. B., McBride, R., \& Wuebker, R. (2017). On opportunities: Philosophical and empirical implications. Academy of Management Review, 42(4), 726-730. https://doi.org/10.5465/amr.2016.0035

Alvarez, S., \& Barney, J. B. (2007). The entrepreneurial theory of the firm. Journal of Management Studies, 44(7), 1057-1063. http://dx.doi. org/10.1111/j.1467-6486.2007.00721.x

Argyres, N. S., \& Zenger, T. R. (2012). Capabilities, transaction costs, and firm boundaries. Organization Science, 23(6), 1643-1657. https://doi. org/10.1287/orsc.1110.0736

Barney, J. (1991). Firm resources and sustained competitive advantage. Journal of Management, 17(1), 99-120. https://doi. org/10.1177/014920639101700108

Barney, J. A. Y., \& Felin, T. (2013). What are microfoundations?. Academy of Management Perspectives, 27(2), 138-155. https://doi.org/10.5465/ amp.2012.0107

Baumol, W. J. (1996). Entrepreneurship: Productive, unproductive, and destructive. Journal of Business Venturing, 11(1), 3-22. https://doi. org/10.1016/0883-9026(94)00014-X

Borkowska, B., Klimczak, B., Klimczak, M., Jakubowski, R., Boruciński, D., \& Mikucka-Kowalczyk, A. (2019). Ekonomia Instytucjonalna. Wrocław: Wydawnictwo Uniwersytetu Ekonomicznego we Wrocławiu.

Briel, F., Davidsson, P., \& Recker, J. (2018). Digital technologies as external enablers of new venture creation in the IT hardware sector. Entrepreneurship Theory and Practice, 42(1), 47-69. https://doi. org/10.1177/1042258717732779

Chandler, G., McKelvie, A., \& Davidsson, P. (2009). Asset specificity and behavioral uncertainty as moderators of the sales growth - employment growth relationship in emerging ventures. Journal of Business Venturing, 24 (4), 373-387. https://doi.org/10.1016/j.jbusvent.2008.04.002

Chen, H. S., Mitchell, R. K., Brigham, K. H., Howell, R., \& Steinbauer, R. (2018). Perceived psychological distance, construal processes, and abstractness of entrepreneurial action. Journal of Business Venturing, 33(3), 296-314. https://doi.org/10.1016/j.jbusvent.2018.01.001 
Davidsson, P., Delmar, F., \& Wiklund, J. (2006). Entrepreneurship and the Growth of Firms. Cheltenham: Edward Elgar Publishing.

Dobbs, M., \& Hamilton, R. T. (2007). Small business growth: recent evidence and new directions. International Journal of Entrepreneurial Behavior \& Research. 13(4), 296-32. https://doi.org/10.1108/13552550710780885

Dominiak, P., Wasilczuk, J., \& Starnawska, M. (2016). Przedsiębiorczość nieproduktywna w świetle ekonomii instytucjonalnej. Analiza zjawiska w Polsce. Gdańsk: Wydawnictwo Politechniki Gdańskiej.

Dvouletý, O., \& Orel, M. (2020). Individual determinants of entrepreneurship in Visegrád countries: Reflection on GEM data from the Czech Republic, Hungary, Poland, and Slovakia. Entrepreneurial Business and Economics Review, 8(4), 123-137.

Foss, N. J. (1993). Theories of the firm: Contractual and competence perspectives. Journal of Evolutionary Economics, 3(2), 127-144. https:// doi.org/10.1007/BF01213830

Foss, N. J., \& Klein, P. G. (2012). Organizing Entrepreneurial Judgment: A new Approach to the Firm. Cambridge: Cambridge University Press.

Foss, N. J., \& Klein, P. G. (2015). The judgment-based approach to entrepreneurship: Accomplishments, challenges, new directions. Journal of Institutional Economics, 11(3), 585-599.

Foss, N. J., \& Klein, P. G. (2017). Entrepreneurial discovery or creation? In search of the middle ground. Academy of Management Review, 42(4), 733-736. https://doi.org/10.5465/amr.2016.0046

Gaglio, C. M., \& Katz, J. A. (2001). The psychological basis of opportunity identification: Entrepreneurial alertness. Small Business Economics, 16(2), 95-111. https://doi.org/10.1023/A:1011132102464

Gancarczyk, M. (2006). Sieci innowacyjne a polityka wspierania małych i średnich przedsiębiorstw (MŚP). Przeglqd Organizacji, (11), 14-17.

Gancarczyk, M. (2017). The process of SME growth: Integrating the Resource-Based and Transaction Cost Approaches. Kraków: Jagiellonian University Press.

Gancarczyk, M. (2019). The performance of high-growers and regional entrepreneurial ecosystems: A research framework. Entrepreneurial Business and Economics Review, 7(3), 99-123. https://doi.org/10.15678/ EBER.2019.070306

Gancarczyk, M., \& Gancarczyk, J. (2013). Structural change in industrial clustersscenarios and policy implications. Studia Regionalia, (35), 111-128.

Gaweł, A. (2013). Proces Przedsiębiorczy: Tworzenie Nowych Przedsiębiorstw. Warszawa: Difin.

Gibbert, M., \& Ruigrok, W. (2010). The "what"and "how"of case study rigor: Three strategies based on published work. Organizational Research Methods, 13(4), 710-737. https://doi.org/10.1177/1094428109351319

Gorynia, M. (1999). Przedsiębiorstwo w nowej ekonomii instytucjonalnej. Ekonomista, 6(99), 778-790. 
Götz, M. (2020a). Primer on the cluster impact on internationalisation in the form of FDI in the time of industry 4.0. European Spatial Research and Policy, 27(1), 195-220.

Götz, M. (2020b). Cluster role in industry 4.0-a pilot study from Germany. Competitiveness Review: An International Business Journal. https://doi. org/10.1108/CR-10-2019-0091

Kirzner, I. (1973). Competition and Entrepreneurship. Chicago: Chicago University Press.

Kirzner, I. M. (1997). Entrepreneurial discovery and the competitive market process: An Austrian approach. Journal of Economic Literature, 35(1), 60-85.

Knight, F. H. (1921). Risk, uncertainty and profit. Boston and New York: Houghton Mifflin.

Li, C., Murad, M., Ashraf, S., Syed, N., \& Riaz, M. (2020). Entrepreneurial nascent behaviour: The role of causation process in opportunity discovery and creation. Entrepreneurial Business and Economics Review, 8(4), 183-200. https://doi.org/10.15678/EBER.2020.080410

Marona, B., \& Tomal, M. (2020). The COVID-19 pandemic impact upon housing brokers' workflow and their clients' attitude: Real estate market in Krakow. Entrepreneurial Business and Economics Review, 8(4), 221-232.

McMullen, J. S., \& Dimov, D. (2013). Time and the entrepreneurial journey: The problems and promise of studying entrepreneurship as a process. Journal of Management Studies, 50(8), 1481-1512. https://doi. org/10.1111/joms.1204

Mitchell, J. R., Mitchell, R. K., \& Randolph-Seng, B. (Eds.). (2014). Handbook of Entrepreneurial Cognition. Cheltenham: Edward Elgar Publishing.

Onwe, C., Ogbo, A., \& Ameh, A. A. (2020). Entrepreneurial orientation and small firm performance: The moderating role of environmental hostility. Entrepreneurial Business and Economics Review, 8(4), 67-84. https://doi. org/10.15678/EBER.2020.080404

Packard, M. D. (2017). Where did interpretivism go in the theory of entrepreneurship?. Journal of Business Venturing, 32(5), 536-549. https://doi.org/10.1016/j.jbusvent.2017.05.004

Penrose, E., \& Penrose, E. T. (2009). The Theory of the Growth of the Firm. Oxford: Oxford University Press.

Pryor, C., Webb, J. W., Ireland, R. D., \& Ketchen, Jr, D. J. (2016). Toward an integration of the behavioral and cognitive influences on the entrepreneurship process. Strategic Entrepreneurship Journal, 10(1), 2142. https://doi.org/10.1002/sej.1204

Ramoglou, S., \& Tsang, E. W. (2016). A realist perspective of entrepreneurship: Opportunities as propensities. Academy of Management Review, 41(3), 410-434. https://doi.org/10.5465/amr.2014.0281

Ramoglou, S., \& Tsang, E. W. (2017). In defense of common sense in entrepreneurship theory: Beyond philosophical extremities and linguistic abuses. Academy of Management Review, 42(4), 736-744. https://doi. org/10.5465/amr.2017.0169 
Reissova, A., Šimsova, J., Sonntag, R., \& Kučerova, K. (2020). The influence of personal characteristics on entrepreneurial intentions: International comparison. Entrepreneurial Business and Economics Review, 8(4), 2946. https://doi.org/10.15678/EBER.2020.080402

Sarason, Y., Dean, T., \& Dillard, J.F. (2006). Entrepreneurship as the nexus of individual and opportunity: A structuration view. Journal of Business Venturing 21(3), 286-305. https://doi.org/10.1016/j. jbusvent.2005.02.007

Schumpeter, J. A. (1911). The Theory of Economic Development. Cambridge, MA: Harvard University Press.

Selden, P. D., \& Fletcher, D. E. (2015). The entrepreneurial journey as an emergent hierarchical system of artifact-creating processes. Journal of Business Venturing, 30(4), 603-615. https://doi.org/10.1016/j. jbusvent.2014.09.002

Shane, S. (2012). Reflections on the 2010 AMR decade award: Delivering on the promise of entrepreneurship as a field of research. Academy of Management Review, 37(1), 10-20. https://doi.org/10.5465/ amr.2011.0078

Shane, S., \& Venkataraman, S. (2000). The promise of entrepreneurship as a field of research. Academy of Management Review, 25(1), 217-226. https://doi.org/10.5465/amr.2000.2791611

Steyaert, C. (2007). 'Entrepreneuring' as a conceptual attractor? A review of process theories in 20 years of entrepreneurship studies. Entrepreneurship and Regional Development, 19(6), 453-477. https:// doi.org/10.1080/08985620701671759

Teece, D. J. (2007). Explicating dynamic capabilities: The nature and microfoundations of (sustainable) enterprise performance. Strategic Management Journal, 28(13), 1319-1350. https://doi.org/10.1002/smj.640

Ujwary-Gil, A., \& Potoczek, R. N. (2020). A dynamic, network and resourcebased approach to the sustainable business model. Electronic Markets, 30(4), 717-733. https://doi.org/10.1007/s12525-020-00431-6

Ujwary-Gil, A. (2019). Organizational network analysis: A study of a university library from a network efficiency perspective. Library \& Information Science Research, 41(1), 48-57. https://doi.org/10.1016/j. lisr.2019.02.007

Ujwary-Gil, A. (2017). The business model and intellectual capital in the value creation of firms: A literature review. Baltic Journal of Management, 12(3), 368-386. https://doi.org/10.1108/BJM-10-2016-0224

Welter, F. (2011). Contextualizing entrepreneurship-conceptual challenges and ways forward. Entrepreneurship Theory and Practice, 35(1), 165184. https://doi.org/10.1111/j.1540-6520.2010.00427.x

Wijaya, P., \& Suasih, N. N. (2020). The effect of knowledge management on competitive advantage and business performance: A study of silver craft SMEs. Entrepreneurial Business and Economics Review, 8(4), 105-121. https://doi.org/10.15678/EBER.2020.080406 
Williamson, O. E. (1985). The Economic Institutions of Capitalism: Firms, Markets, Relational Contracting. New York: Free Press.

Williamson, O. E. (1989). Transaction cost economics. Handbook of Industrial Organization, (1), 135-182.

Williamson, O. E. (1991). Comparative economic organization: The analysis of discrete structural alternatives. Administrative Science Quarterly, 36(2), 269-296. https://doi.org/10.2307/2393356

Zahra, S. A., \& Wright, M. (2011). Entrepreneurship's next act. Academy of Management Perspectives, 25(4), 67-83. https://doi.org/10.5465/ amp.2010.0149

\begin{abstract}
Abstrakt
Cel: Wyjaśnienie przedsiębiorczych wyborów jest istotne dla efektywnej alokacji zasobów oraz zamożności jednostek i społeczeństw. Studia z zakresu ekonomii i nauk o zarządzaniu przedstawiajq zarówno komplementarne, jak i alternatywne poglady na temat decyzji i działań przedsiębiorców. Niniejszy artykuł ma na celu przedstawienie syntezy tej dyskusji, zaproponowanie podejścia procesowego i konfiguracyjnego, które łączy istniejq̨ce ujęcia teoretyczne, a także określenie wkładu artykułów z tego tomu do badań nad zwiqzzkiem między przedsiębiorczym poznaniem a wyborami. Metodyka: Na podstawie narracyjnego przeglaqdu literatury scharakteryzowano główne koncepcje opisujqce sposoby dokonywania przez przedsiębiorców osq̨ów oraz podejmowania decyzji i działań w warunkach niepewności. Następnie, zaproponowano wykorzystanie tych podejść w ujęciu procesowym i konfiguracyjnym. Wyniki: Badania przedstawione $w$ tym tomie traktuja koncepcje przedsiębiorczego odkrywania i tworzenia jako komplementarne, a nie alternatywne. Ponadto, badania te potwierdzaja znaczenie zdolności, cech osobowości i percepcji przedsiębiorcy dla wyników firmy i decyzji o prowadzeniu działalności gospodarczej. Wartościq tego tomu jest także uwzględnienie szerokiego kontekstu i specyficznych uwarunkowań zwiqzanych z położeniem geograficznym, cechami branż i przedsiębiorstw, a także rozwojem gospodarczym i społecznq świadomościq. Implikacje dla teorii i praktyki: Artykuł dokonuje syntezy dyskusji na temat uwarunkowań przedsiębiorczych wyborów i proponuje podejścia procesowe i konfiguracyjne, które łączq istniejqce na ten temat poglady. Oryginalność i wartość: Wkład do literatury na temat wyborów przedsiębiorczych opiera się na wskazaniu powiq̨zań między rozumieniem osq̨dów i zachowań przedsiębiorczych w ekonomii i naukach o zarządzaniu oraz na określeniu, w jaki sposób badania w obecnym numerze tematycznym wyjaśniaja te powiqzania.
\end{abstract}

Słowa kluczowe: niepewność, szansa, przedsiębiorcze poznanie, przedsiębiorczy osq̨, teoria firmy 


\section{Biographical notes}

MartaGancarczyk,Ph.D.,Hab.,AssociateProfessoratthe InstituteofEconomics, Finance and Management, Jagiellonian University in Krakow, Poland. Her research, publication and consulting activities focus on entrepreneurship, firm growth, technology management and commercialization, industrial clusters, as well as innovation systems and policies. She is an Associate Editor of the international scientific journal entitled Journal of Entrepreneurship, Management and Innovation (JEMI), and a Member of the Editorial Advisory Board of the Journal of Organizational Change Management.

Anna Ujwary-Gil, Ph.D., Hab., Associate Professor at Institute of Economics, Polish Academy of Sciences (Laboratory of Process and Network Analysis) in Warsaw, Poland, where she is also a director of two MBA programs. She is the Editor-in-Chief of the international and scientific journal named Journal of Entrepreneurship, Management and Innovation (JEMI). She is also the founder and president of the Cognitione Foundation for the Dissemination of Knowledge and Science. Her research interests include organizational network analysis, knowledge management, intellectual capital, resourcebased views, and dynamic approaches to organization and management.

\section{Conflicts of interest}

The authors declare no conflict of interest.

\section{Citation (APA Style)}

Ganacarczyk, M., \& Ujwary-Gil, A. (2021). Entrepreneurial cognition or judgment: Management and economics approaches to the entrepreneur's choices. Journal of Entrepreneurship, Management and Innovation, 17(1), 7-23. https://doi.org/10.7341/20211710 